K A N D A I

\begin{tabular}{|l|l|l|}
\hline Volume 16 & No. 1, Mei 2020 & Halaman 111-124 \\
\hline
\end{tabular}

\title{
SUBJEK PSIKOTIK DALAM CERPEN "KELUARGA M" KARYA BUDI DARMA \\ (Psychotic Subjects in The Short Story “Keluarga M" by Budi Darma)
}

\author{
Galih Pangestu Jati \\ Fakultas Ilmu Budaya, Universitas Gadjah Mada \\ Jalan Sosio Humaniora Bulaksumur, Sagan, Caturtunggal, Kec. Depok, \\ Kabupaten Sleman, Daerah Istimewa Yogyakarta, Indonesia \\ Pos-el: gpangestujati@gmail.com
}

(Diterima: 4 Januari 2020; Direvisi: 20 Februari 2020; Disetujui: 21 April 2020)

\begin{abstract}
This study aimed to explain the movement of the subject in a short story. In addition, this study also looked at the subjectivity of Budi Darma. The material object used in this study is the short story "Keluarga M" by Budi Darma, while the theory used is a theory about the subject and gaze developed by a post-marxist figure, Slavoj Žižek. The method used in this research is qualitative method. The results of this study showed that the subject in the short story "Keluarga M" by Budi Darma continues to experience movement. He constantly tried to get out of the symbolic and social dimensions and this effort was successful. The subject also had experienced lack and tried to reach the imaginary. As a result, the subject had experienced cynicism, which was conscious of doing the wrong thing, but still he did. Furthermore, at one time, the subject had entered in an empty moment and became a psychotic subject because it could be distance from the symbolic and social dimensions. However, the subject was only able to move there, he was unable to carry out any radical actions. The subject instead returns to the symbolic and social dimensions. Then, Budi Darma's subjectivity appeared from his failure to form a radical subject and only formed a psychotic subject.
\end{abstract}

Keywords: subjectivity, Budi Darma, "Keluarga M" short story, psychotic subject

\begin{abstract}
Abstrak
Penelitian ini bertujuan menjelaskan pergerakan subjek dalam cerpen "Keluarga M". Selain itu, penelitian ini juga melihat subjektivitas Budi Darma. Adapun objek material yang digunakan di dalam penelitian ini adalah cerpen "Keluarga M" karya Budi Darma, sedangkan teori yang digunakan adalah teori mengenai subjek dan gaze atau tatapan yang dikembangkan oleh tokoh post-marxist, Slavoj Žižek. Metode yang digunakan dalam penelitian ini adalah metode kualitatif. Adapun hasil dari penelitian ini adalah subjek di dalam cerpen "Keluarga M" karya Budi Darma terus mengalami pergerakan. Ia terusmenerus berusaha untuk keluar dari dimensi simbolik dan sosial dan usaha ini pun berhasil. Subjek pun sempat mengalami lack dan mencoba untuk meraih yang imajiner. Akibatnya, subjek sempat mengalami sinis, yakni sadar melakukan hal yang salah, tetapi tetap ia lakukan. Selanjutnya, pada satu saat, subjek sempat masuk dalam momen kosong dan menjadi subjek psikotik karena bisa berjarak terhadap dimensi simbolik dan sosial. Namun, subjek hanya mampu bergerak sampai di situ, ia tidak mampu melakukan tindakan radikal apa pun. Subjek malah kembali kepada dimensi simbolik dan sosial. Kemudian, subjektivitas Budi Darma tampak dari kegagalannya dalam membentuk subjek radikal dan hanya membentuk subjek psikotik.
\end{abstract}

Kata-kata kunci: subjektivitas, Budi Darma, cerpen "Keluarga M", subjek psikotik 
DOI: $10.26499 / j k . v 16 i 1.1989$

How to cite: Jati, G. P. (2020). Subjek psikotik dalam cerpen "Keluarga M" karya Budi Darma. Kandai, 16(1), 111-124 (DOI: 10.26499/jk.v16i1.1989)

\section{PENDAHULUAN}

Budi Darma memang dikenal sebagai salah satu sastrawan produktif di Indonesia. Selama hidupnya, ia sudah menulis banyak karya sastra. Tulisannya telah tersebar di berbagai media massa dan telah menerbitkan beberapa buku, seperti Olenka, Rafillus, Ny. Talis, dan lain-lain. Akan tetapi, awal kariernya sebagai sastrawan dimulai dari terbitnya secara khusus keempat cerpennya, yakni "Kritikus Adinan", "Dua Laki-Laki", "Secarik Surat", dan "Laki-Laki Setengah Umur" di majalah Horison No. 4 April 1974 (Rampan, 1982, hlm. 296). Cerpennya yang berjudul "Kritikus Adinan" pernah dibahas oleh Teeuw dalam bukunya Sastra Indonesia Modern II (1989). Menurutnya, keganjilan yang dilukiskan di dalam cerpen ini ditegaskan secara paradoksal dalam gaya penulisan yang khas (Teeuw, 1989, hlm. 200). Hal yang sama juga terlihat dalam cerpennya yang dibahas dalam tulisan ini, "Keluarga M".

Secara keseluruhan, cerpen ini bercerita mengenai tokoh saya yang hidup di sebuah apartemen di Amerika Serikat. Ia tinggal seorang diri di sebuah apartemen yang padat penduduk. Meskipun kondisinya demikian, tokoh saya masih merasa tenang tinggal di apartemen tersebut. Namun, ketenangannya itu berakhir sejak tokoh saya mendapati mobil mewahnya dibuat lecet oleh orang yang tidak ia kenali. Oleh karena berang, ia pun sempat melaporkan kepada manajemen apartemen walau tentu saja hasilnya nihil karena sesuai peraturan, mobil penghuni menjadi tanggung jawab penghuni sendiri. Tokoh saya pun memutuskan untuk mencari tahu sendiri siapa pelakunya dengan sering-sering mengawasi lapangan sampai ia mencurigai sepasang kakak beradik.

Tokoh saya pun terus-menerus mengintai sepasang kakak beradik itu. Sampai suatu hari, ia memergoki sang adik membawa paku ketika sedang mengintip jam yang ada di dalam mobil tokoh saya. Tokoh saya pun geram dan tidak segan-segan untuk menunjuk mereka sebagai pelaku perusakan mobil yang ia cari. Ia pun menanyai identitas kakak beradik itu dan menanyakan latar belakang keluarganya. Dengan kemarahan yang memuncak, tokoh saya pun mendatangi keluarga kakak beradik tersebut dan mengadukan perbuatan yang dilakukan oleh anaknya. Namun, sayangnya respons kedua orang tua anak tersebut tidaklah sesuai dengan yang diharapkan oleh tokoh saya. Kedua orang tua itu masih membela kedua anaknya dan berdalih bahwa selama ini keduanya telah dididik secara baik. Respons ini pun membuat tokoh saya kalap dan menyimpan dendam terhadap keluarga tersebut.

Setelah peristiwa itu, tokoh saya pun terus-menerus terobsesi ingin menghancurkan keluarga tersebut. Ia selalu ingin membuat keluarga itu mengalami cacat seumur hidup. Ia pun melakukan berbagai cara untuk menyakiti keluarga tersebut, terutama kakak beradik yang ia tuduh menjadi pelaku perusakan mobil mewahnya. Ia sengaja meminta pengelola apartemen untuk menghadirkan gerai Coca Cola di apartemen tersebut supaya banyak botol yang pecah dan menyakiti adik kakak tersebut walau hasilnya tentu saja nihil. Sampai pada suatu hari, ia mendapat kabar bahwa keluarga tersebut mengalami kecelakaan yang cukup parah. Akibat kecelakaan tersebut, satu keluarga mengalami cacat permanen. 
Namun, bukannya bahagia karena keinginannya terkabul, tokoh saya malah mengalami guncangan yang sangat mengerikan. Ia menjadi linglung dan menjauh dari yang simbolik.

Dari ringkasan cerita yang telah dipaparkan tersebut dapat dilihat bahwa Budi Darma dalam cerpen "Keluarga M" menghadirkan tokohnya sebagai subjek yang dinamis. Ia bergerak terus-menerus untuk melakukan perlawanan terhadap yang simbolik, tetapi selalu gagal. Pergerakan subjek ini disebabkan oleh adanya hasrat dan fantasinya. Meski demikian, ketika objek hasratnya menghilang, ia menjadi terguncang. Dalam keterguncangan tersebut, ia mengalami momen kosong. Ia menjadi subjek yang psikotik, yakni subjek yang memiliki jarak terhadap yang simbolik. Kemudian, tidak lama setelah itu, subjek pun kembali kepada tatanan simbolik. Dari pemaparan tersebut, dalam tulisan ini akan dibahas mengenai pergerakan subjek dalam cerpen "Keluarga M" karya Budi Darma. Dengan demikian, hal-hal yang dibahas meliputi pergulatan subjek dengan yang simbolik sehingga ia menjadi subjek yang psikotik.

Ada beberapa penelitian yang telah dilakukan terkait dengan subjek dalam karya sastra. Penelitian pertama berjudul "Subjektivitas Pramoedya Ananta Toer dalam Novel Perburuan: Kajian Psikoanalis Historis Slavoj Žižek" (Akmal, 2015). Dalam penelitian ini, Akmal mencoba menguraikan subjektivitas Pramudya Ananta Toer dalam tindakannya menulis novel Perburuan. Menurutnya, tindakan ini dilakukan untuk membangun jarak dan melepaskan diri dari yang simbolik. Dengan menggunakan konsep subjek Slavoj Žižek dan metode sudut pandang Tzvetan Todorov, hasil penelitian ini menunjukkan bahwa subjektivitas Pram ketika melakukan tindakan penulisan novel Perburuan menunjukkan karakteristik yang dapat dikatakan radikal terhadap beberapa dimensi simbolik yang dominan di sekelilingnya.

Penelitian lainnya ialah "Fantasi Ideologis dalam Novel The White Tiger Karya Aravind Adiga: Perjumpaan Subjek-Subjek Sastra melalui Prespektif Slavoj Žižek" (Setiawan, 2016). Hasil dari penelitian itu ialah bahwa karya sastra sebagai suatu kritik justru memperlihatkan bagaimana fantasi ideologis hadir sebagai hasil dari sinisme masyarakat di tengah kapitalisme kultural. Sinisme merupakan proses ideologis mengenai subjek yang tenggelam dalam tatanan simboliknya. Selain itu, penelitian lainnya yang berhubungan dengan subjektivitas Slavoj Žižek ialah penelitian yang membahas pergerakan subjek dalam cerpen "Matinya Seorang Penari Telanjang" karya Seno Gumira Ajidarma (Zamzuri, 2018). Penelitian itu menunjukkan bahwa subjek melakukan tindakan radikal dengan menjadi penari telanjang (stripper) yang secara akal sehat (common sense) itu melawan dimensi simbolik atau sosial. Selanjutnya, subjek mengalami pelesapan (lack) dan mengejar yang imajiner sehingga subjek mengalami sinisme, yaitu tahu dengan hal yang salah, tetapi pura-pura tidak tahu bahwa itu salah, dan kynicism, yaitu menolak simbolik kampungan melalui ironi dan sarkasme. Subjek pun pada akhirnya tidak mampu melawan yang simbolik. Apabila dilihat dari penelitianpenelitian sebelumnya, dapat dilihat bahwa penelitian terhadap cerpen "Keluarga M" karya Budi Darma belum pernah dilakukan.

\section{LANDASAN TEORI}

Dalam penelitian ini, teori yang akan digunakan ialah teori mengenai subjektivitas yang digagas oleh Slavoj Žižek. Dalam konsep ini, (S. Žižek, 
2008, hlm. 182) meminjam konsep psikoanalisis Lacan, yakni yang real, yang simbolik, dan yang imajiner. Secara sederhana, yang real diartikan sebagai tataran yang belum terbahasakan atau tataran yang masih prasimbolik. Sementara itu, yang simbolik diartikan sebagai struktur persepsi tentang realitas. Kemudian, yang imajiner merupakan ekses yang diakibatkan ketakmungkinan yang simbolik dalam menamai yang real (Robert, 2013, hlm. 60). Pada tataran ini bisa dirunut melalui tahap cermin, yakni keterpisahan antara dirinya dan imaji mengenai dirinya. Keterpisahan ini yang mendorong subjek menjadi terbelah dan mencapai puncaknya dalam trauma yang menyebabkan subjek bertindak radikal (Akmal, 2015, hlm. 15).

Pada dasarnya, tindakan radikal merupakan tindakan yang termasuk kategori destruktif sebab tindakan radikal merupakan upaya penghancuran terhadap yang simbolik. Hal-hal yang telah terbahasakan, tertulis, tersejarahkan telah terperangkap dalam jaring-jaring simbolik (S. Žižek, 2008, hlm. 150). Tindakan radikal di sini berkenaan dengan momentum, bukan proses yang melibatkan rencana, tujuan, maksud, kesenjangan, dan lain sebagainya. Tindakan ini merupakan tindakan subjek yang ingin keluar dari eksterioritas yang menghakiminya, baik itu dari apa yang di baliknya maupun dari apa yang ada di luarnya. Dengan demikian, tindakan ini hadir dengan sendirinya sebagai suatu ledakan yang mengejutkan, kemuakan atas kepalsuan yang mengaburkan realitas. Tindakan radikal akan terjadi di luar kesadaran yang tanpa rencana dan tanpa tujuan (Setiawan, 2016, hlm. 56).

Oleh karena itu, ketika subjek melakukan tindakan radikal, ia memiliki jarak dengan yang simbolik. Pada saat seperti ini, kondisi subjek menjadi psikotik, yakni subjek yang mempertahankan semacam jarak dari tatanan simbolik (S. Žižek, 2008, hlm. 186). Menurut Žižek (S. Žižek, 2008, hlm. 91), kondisi psikosis merupakan kondisi yang dipahami sebagai keadaan "di luar kewajaran". Subjek yang berada pada kondisi ini merupakan subjek yang ditolak, diambilalih, dikecualikan oleh alam semesta simbolik.

Kemudian, dalam membahas keterkaitan Žižek dengan karya sastra akan digunakan teori gaze atau tatapan. Žižek (S. Žižek, 1996, hlm. 90) mengembangkan teori yang digagas oleh Lacan mengenai gaze. Pada dasarnya, Lacan (S. Žižek, 1996, hlm. 90) berpendapat bahwa gaze merupakan objek. Gaze bukanlah sesuatu yang melihat subjek, tetapi sesuatu yang dilihat oleh subjek. Ia menganalogikan gaze dengan film. Ketika menonon film, penonton tidak bisa menafikan bahwa ia melihat hal-hal yang tidak dilihat oleh subjek yang ada di dalam film tersebut. Oleh karena itu, subjek dapat diterjemahkan sebagai sudut pandang, bukan dari kacamata penonton, lebih tepatnya sutradara - atau dalam ranah sastra adalah pengarang sebagai subjek. Apabila panggilan gaze dipenuhi oleh subjek, subjektivitas yang dihadirkan ke dalam karya sastra akan menjadi subjektivitas simbolik, tetapi apabila panggilan gaze menjadi panggilan yang otentik, subjektivitas akan hadir sebagai yang real.

\section{METODE PENELITIAN}

Metode penelitian adalah cara untuk memperoleh pengetahuan mengenai objek tertentu dan karenanya harus sesuai dengan kodrat keberadaan objek itu sebagaimana yang dinyatakan oleh teori (Faruk, 2012, hlm. 55). Dalam penelitian ini dilakukan dua tahapan penelian, yakni pengumpulan data dan analisis data. Adapun data yang dimaksud dalam penelitian ini adalah 
satuan tekstual yang berhubungan dengan teori subjektivitas perspektif Slavoj Žižek.

Data dapat dibedakan menjadi dua, yakni data primer dan data sekunder. Data primer terdiri dari frasa, kalimat, dan paragraf yang didapat dari cerpen "Keluarga M" karya Budi Darma, yang berhubungan dengan teori. Kemudian, data sekunder merupakan teks historis, sosial, dan kultural yang mendukung, yang berhubungan dengan objek penelitian.

Metode dan teknik pengumpulan data pada dasarnya adalah seperangkat cara atau teknik yang merupakan perpanjangan dari indera manusia karena tujuannya ialah mengumpulkan faktafakta empirik yang terkait dengan masalah penelitian (Faruk, 2012, hlm. 25). Langkah pengumpulan data diawali dengan pembacaan berulang terhadap objek material, yakni cerpen "Keluarga M" karya Budi Darma. Kemudian mengelompokkan data yang sesuai dengan landasan teori dan fokus penelitian. Selain dari cerpen, juga dikumpulkan data yang berasal dari jurnal, buku-buku, dan kertas kerja lainnya yang berhubungan dengan pengarang dan cerpen.

Langkah selanjutnya ialah analisis data. Analisis data merupakan seperangkat cara atau teknik penelitian yang merupakan perpanjangan dari pikiran manusia karena fungsinya bukan untuk mengumpulkan data, melainkan untuk mencari hubungan antardata yang tidak akan pernah dinyatakan sendiri oleh data yang bersangkutan (Faruk, 2012, hlm. 25).

Dalam tahap ini, variabel-variabel yang ditemukan dalam proses pengumpulan data akan dicari hubungannya satu sama lain sehingga menjadi satu kesatuan. Dari pemaparan latar belakang masalah yang sudah diidentifikasi sebelumnya, dalam tulisan ini dibahas pergerakan subjek dalam cerpen "Keluarga M" karya Budi Darma. Dengan demikian, hal-hal yang dibahas meliputi pergulatan subjek dengan yang simbolik sehingga ia menjadi subjek yang psikotik.

\section{PEMBAHASAN}

\section{Subjek psikotik dalam cerpen "Keluarga M"}

Untuk melihat pergerakan subjek dalam cerpen "Keluarga M", perlu dilakukan pembahasan mengenai dimensi simbolik yang mengungkung tokoh saya dalam cerpen tersebut. Dimensi yang menjerat tokoh saya ialah dimensi sosial tempat tokoh saya tinggal. Hal ini disebabkanbahwa sepanjang cerita, latar tempat yang digunakan di dalam cerpen ini ialah apartemen di Indiana, Amerika Serikat. Tokoh saya digambarkan sebagai seorang laki-laki yang tinggal sendiri apartemennya. Hidupnya sudah tergolong mapan dan memiliki pekerjaan yang tetap. Meski demikian, ia tinggal di antara para tetangga apartemen yang semuanya sudah berkeluarga, seperti yang terlihat pada kutipan berikut.

Sudah lama saya tinggal di gedung raksasa yang memuat dua ratus apartemen ini, dan mungkin sayalah satu-satunya yang hidup sendirian tanpa anak dan istri. Selama ini, saya tidak pernah terganggu. Meskipun saya tidak pernah mempunyai citacita untuk mempunyai anak, saya tidak berkeberatan melihat anak-anak menghabiskan waktunya di lapangan bermain di sebelah utara gedung. Lapangan ini dapat saya lihat dari jendela apartemen saya di tingkat delapan (Darma, 2004, hlm. 55).

Kutipan yang menjadi pembuka cerpen tersebut memperlihatkan dimensi 
simbolik yang mengungkung tokoh saya, yakni masyarakat urban yang memiliki keluarga. Mereka memiliki istri dan anak-anak. Oleh karena hal itu, keperluan yang berkaitan dengan keluarga dan anak-anak selalu diutamakan daripada keperluan individu.

Apabila dilihat lebih lanjut, cerpen ini berlatar waktu tahun 1970-an dan berlatar tempat di Amerika Serikat. Tahun 1970-an merupakan tahun pergeseran budaya di sana. Dekade ini merupakan perpanjangan dari perjuangan para aktivis yang berjuang sejak dekade sebelumnya. Adapun pergeseran budaya yang terjadi sangat mencolok terlihat pada anak muda di sana. Berkaitan dengan seksualitas, pada akhir dekade 1970-an, anak muda sudah banyak yang meninggalkan seksualitas tradisional. Hubungan seks di luar nikah dan pembebasan akan otoritas individu menjadi semangat yang ingin diusung. Namun, walaupun pergeseran budaya mulai terjadi, itu tidak berarti pandangan konservatis sudah bergeser begitu saja. Sebaliknya, masih ada pandanganpandangan konservatif yang dipercaya oleh sebagian besar masyarakat, termasuk dalam lingkungan tokoh saya tempat ia tinggal di sebuah apartemen tersebut. Hal ini dapat dilihat dari penghuni apartemen yang hampir semuanya berkeluarga. Di sini dapat dilihat adanya upaya tokoh saya untuk keluar dari jeratan yang simbolik.

Dalam perspektif Žižek, tindakan untuk keluar dari yang simbolik (sosial) dengan menanggalkan segala hal yang melekat pada dirinya, semisal ideologi, moralitas, melanggar norma, dan membuang konsensus sosial dikatakan sebagai tindakan radikal. Kata lainnya, tindakan radikal dapat diartikan sebagai 'tindakan yang tidak tahu diri' sebab 'diri' adalah konstruksi budaya hegemonik (Arifin, 2016, hlm. 50). Seperti dijelaskan sebelumnya, tokoh saya tinggal di lingkungan yang masyarakatnya masih cenderung konservatif. Hal ini ditandai dengan para penghuni apartemen yang hampir semuanya memiliki keluarga. Sementara itu, hal ini bertolak belakang dengan tokoh saya. Tokoh saya memilih untuk tinggal sendiri, tanpa istri dan anak. Keputusan ini tidak didasari atas kepentingan atau ideologi tertentu, tetapi hanya melanggar konstruksi budaya yang berlaku di sekelilingnya. Ia pun menjadi subjek yang psikotik karena dapat berjarak dengan yang simbolik.

Tidak hanya berhenti di situ, ia pun berupaya lepas dari jerat yang simbolik lainnya. Seperti disepakati di masyarakat mana pun, ada semacam aturan bahwa orang dewasa harus mengasuh dan mengalah terhadap anakanak, bahkan mereka yang merasa terganggu dengan anak-anak malah memilih untuk berpindah tempat tinggal seperti yang terlihat pada kutipan berikut.

Kadang-kadang saya heran mengapa banyak orang tidak kerasan tinggal di sini. Ada yang mengeluh gedung ini jauh dari sekolah anak-anak mereka, ada yang menyatakan penyesalannya mengapa gedung ini dulu dibangun dekat jalan raya federal, dengan demikian lalu lintas bising dan membahayakan anak-anak, dan ada yang jengkel karena di sini terlalu banyak anak, dan karena itu suasana menjadi gaduh, ada juga yang mengeluh karena anak-anak di sini nakal, sering berkelahi, dan merugikan anak mereka sendiri. Bahwa gedung ini jauh dari tempat umum, toh semua yang tinggal di sini mempunyai mobil. Bahwa mereka repot karena anak mereka, kan semua ini akibat mereka mempunyai anak (Darma, 2004, hlm. 55-56) 
Tokoh saya merasa nyaman hidup sendiri di apartemen tersebut. Ia pun merasa heran dengan para penghuni yang pergi dengan alasan jauh dari pusat kota dan tidak nyaman dengan kehadiran anak-anak di sana. Hal ini pun mengindikasikan bahwa anak-anak di dalam lingkungan tokoh saya harus dispesialkan. Orang dewasa memilih untuk mengalah daripada menundukkan anak-anak di sana. Konstruksi inilah yang ingin dilawan oleh tokoh saya. Ketika memiliki masalah dengan anakanak di sana, ia tidak mau mengalah. Ia malah ingin menghakimi anak-anak tersebut ketika ia mempunyai masalah dengan mereka.

... Nah, pada saat saya akan membuka pintu mobil, barulah saya ketahui bahwa mobil saya mengalami cacat baru, sama dengan dulu. Kurang ajar! Dan pada waktu saya berpaling ke sana ke sini, saya mendengar seorang anak berteriak, "Jangan lari! Jangan lari!" Saya bergegas menuju sumber suara, dan tahulah saya bahwa si adik lari dibuntuti oleh si abang yang melarangnya lari. Dan ketika saya mendekati si adik, tahulah saya bahwa manusia kecil ini memegang sebuah paku tua. Tentu dialah penjahatnya. Saya pegang dia, dan menangislah dia meronta-ronta. "Kamu anjing buduk mempunyai maksud jahat untuk merusak mobil saya, ya?! Heh, jawab!" seru saya sambil mengguncang-guncangkan tubuh bajingan kecil itu. Ketika si abang berusaha melerai, saya tarik rambutnya. Dia menjerit, matanya berkaca-kaca. "Kamu berdua bajingan, ya! Kamu berdua mau menghancurkan mobil saya, ya?! Jawab, anjing buduk!" Si abang menggeleng. Ketika saya tanyai, dia mengaku bernama Mark, dan adiknya Martin (Darma, 2004, hlm. 59-60).
Tokoh saya dalam kutipan ini beberapa waktu lalu mendapati mobilnya mengalami kecacatan yang disebabkan oleh benda tajam. Kemudian, ia pun menjadi was-was dan mencurigai beberapa anak yang berpotensi menjadi penyebab kecacatan mobilnya tersebut. Tak lama setelah kejadian pertama, ia mendapati lagi motornya mengalami kecacatan. Saat mengetahui hal tersebut, ia pun langsung menyangkakan pelakunya kepada dua anak-anak, yakni dan Mark dan Martin. Meskipun mereka anak-anak dan belum terbukti bersalah, mereka nyatanya tetap mendapat hardikan dari tokoh saya, bahkan tidak hanya sekali, tetapi berkali-kali. Hal ini terlihat dalam kutipan lain berikut.

Ketika elevator macet, pada suatu sore menjelang jam lima saya turun melalui tangga darurat. Dan ketika saya mencapai tingkat tiga, saya mencium bau tidak enak. Setelah saya mencapai tingkat dua, tahulah saya apa sebabnya. Si adik sedang membongkok, wajahnya tampak kesakitan, dan celananya yang bobrok melembung bagian belakangnya. Dan si abang berusaha menenangkan si adik. "Anjing buduk! Kamu berak, ya?" teriak saya. Ingin rasanya saya membawa parang, memotong kaki dan tangan mereka satu per satu, dan membuat mereka cacat seumur hidup. Si abang mengaku terus terang bahwa si adik sakit perut dan terpaksa berak di situ sebelum sempat mencapai kakus umum di lobby tingkat satu. "Mengapa kamu tidak berak di rumah, anjing buduk?" tanya saya berang. Si abang menjelaskan bahwa tadi mereka sudah akan masuk apartemen mereka, tapi orang tua mereka belum juga datang, padahal kunci yang biasanya diserahkan kepada si abang terbawa mereka (Darma, 2004, hlm. 63). 
Ketika ia akan ke apartemennya menggunakan tangga darurat, ia mendapati kedua anak yang disangka merusak mobilnya sedang berada di sana. Si adik saat itu sedang berak di celana karena tidak tahan ingin segera buang air besar. Hal ini ternyata membuat tokoh saya naik pitam. Ia lagilagi menghardik kedua anak tersebut hanya karena urusan sepele tersebut. Yang dilakukan oleh tokoh saya memang tidak sesuai dengan kesepakatan eksterioritas atau dimensi sosial dan simbolik yang menaunginya. Dalam dimensi simboliknya, perbuatan kedua anak tersebut seharusnya bisa ditoleransi, seperti yang dilakukan oleh tokoh lain dalam kutipan berikut.

Jerry kemudian pergi, dan sebelum menikung ke gang di hallway, dia berhenti, menoleh pada saya, lalu berkata, "Mark bilang kamulah yang meludah. Mbok jangan berbuat demikian. Masak ada anak berak karena sakit perut saja, kamu meludahi lantai, meludahi tembok, dan meludahi pegangan tangga darurat. Itu kan perbuatan sengaja yang merugikan orang lain. Jangan begitu, ya, Bung?" (Darma, 2004, hlm. 64-65)

Tokoh saya marah besar ketika mengetahui bahwa yang membersihkan sisa berak itu adalah petugas kebersihan di apartemen. Ia memarahi petugas kebersihan yang bernama Jerry karena mau membersihkan berak. Namun, Jerry memberi respons yang di luar dugaan tokoh saya. Ia malah menyayangkan sikap tokoh saya yang berlebihan ketika menyikapi anak yang berak tersebut. Hal ini menunjukkan bahwa tokoh saya memang berjarak dari jerat dimensi simbolik yang mengungkungnya selama ini. Ia pun menjadi subjek yang psikotik karena mampu berjarak dengan yang simbolik walaupun dalam batas-batas tertentu.

\section{Upaya Pemenuhan Hasrat yang Lain}

Kemudian, di sisi lain, tokoh saya sebagai subjek mengalami keterbelahan. Ia memang sudah memenuhi the other dengan menjadi subjek psikotik. Namun, di sisi lain ia memang harus tunduk patuh terhadap apa yang diinginkan oleh the other. Hal inilah yang menyebabkan subjek menjadi lack. Pemenuhan hasrat terhadap subjek tidak pernah selesai. Di sini dapat dilihat adanya upaya tokoh saya untuk memenuhi the other yang lain. Hal ini dapat dilihat dalam kutipan berikut.

Tentu saja, ketika saya bertemu dengan si abang dan si adik, saya labrak si abang. Saya sesalkan benar mengapa dia sampai hati mengadu kepada Jerry. Atas labrakan ini si abang tidak tampak gentar. Katanya, dia memberi tahu Jerry karena Jerry menanyainya, dan karena orang tuanya tidak pernah memberinya wewenang untuk berkata bohong. Tanpa diberi tahu pun Jerry akan tahu bahwa yang meludah itu saya, kata si abang selanjutnya. Kali ini ingin rasanya saya membawa gunting, dan memotong lidah si abang, dan membuatnya cacat seumur hidup (Darma, 2004, hlm. 65).

Kutipan di atas menunjukkan bahwa tokoh saya mengalami lack. Ia marah besar karena ketahuan melakukan hal-hal yang tidak sesuai dengan norma yang berlaku. Namun, ia tidak bisa memenuhi hasrat kemarahan tersebut. Oleh karena itu, tokoh saya pun menjadikan anak yang melaporkannya sebagai objek hasrat kemarahannya. Meski demikian, hal ini tidak menjadikan tokoh saya hasratnya terpenuhi. Oleh karena itu, ia pun 
berupaya untuk keluar dari dimensi simbolik yang lain untuk memenuhi hasratnya tersebut. Ia ingin memotong lidah si abang yang telah melaporkan perbuatannya dan menjadikan anak tersebut mengalami cacat seumur hidup.

Tidak hanya sekali, upaya ini pun dilakukan oleh tokoh saya berkali-kali. Pada kutipan yang lain, terlihat ia ingin membuat keluarga $M$ mengalami kecacatan dengan menembaki mereka sekeluarga, seperti yang terlihat dalam kutipan berikut.

Semenjak saat itu, setiap saya melihat Mark dan Martin bermain-main, ingin rasanya saya memiliki senapan, menembak kaki dan tangan mereka, membuat mereka cacat selamalamanya. Dan kemudian saya ketahui, bahwa setiap Sabtu dan Minggu sore pasti mereka bermain-main dengan orang tua mereka. Mereka lari-lari, main bandulan, merry go round, monkey bars, dan keluar masuk lubang setumpukan tong bersamasama. Saya sering melihat Marion menciumi anak-anaknya, dan Melvin menciumi Marion. Ingin rasanya saya menembaki kaki dan tangan mereka, dan membuat mereka cacat seumur hidup. Ingin juga rasanya saya turun membawa parang, dan membuat putus semua kaki dan tangan mereka. Ingin, ingin sekali (Darma, 2004, hlm. 62).

Tokoh saya menyangka kedua anak Melvin dan Marion, yakni Mark dan Martin, telah merusak mobilnya. Hal ini membuat tokoh saya marah besar. Namun, ketika ia melabrak keluarga tersebut, tokoh saya menjadi semakin marah karena responsnya tidak sesuai dengan apa yang ia inginkan. Mereka sekeluarga masih berusaha membela diri meskipun sudah dijadikan objek hasrat kemarahan tokoh saya.
Hasrat kemarahannya pun malah semakin besar dan ia pun membayangkan untuk menembaki keluarga tersebut. Ia ingin menembaki kaki dan tangan mereka, kemudian membuat mereka sekeluarga mengalami kecacatan seumur hidup. Selain itu, ia ingin turun dengan membawa parang menuju mereka. Kemudian, ia ingin menebas kaki dan tangan mereka sampai putus hingga keluarga tersebut mengalami kecacatan permanen. Keinginannya ini berkali-kali muncul dalam benak tokoh saya. Bahkan ia pun merencanakan strategi untuk mencelakai keluarga tersebut.

Dan entah mengapa saya menjadi haus, kemudian jengkel karena gedung sebesar ini, yang jauh dari tempat umum, tidak ada mesin penjual Coca Cola. Kemudian saya berjalan menuju jembatan. Nah, di situlah saya melihat sebuah botol Coca Cola pecah. Andaikata, ya, andaikata saja si abang dan si adik terjatuh dan kepalanya termakan oleh pecahan botol, pikir saya. Pikiran mengenai botol ini menjadi subur ketika pada suatu hari saya membaca sebuah pengumuman bahwa RA akan pindah ke Lexington, Kentucky, dan siapa yang berminat untuk menjadi RA hendaknya mengisi formulir yang tersedia di kantor. Dari semua pelamar akan dipilih tiga orang calon oleh Pimpinan Badan Kerja Sama Apartemen Kota, dan siapa di antara tiga orang ini yang akan menjadi RA, terserah pada hasil pemilihan penghuni gedung (Darma, 2004, hlm. 65-66).

Dalam kutipan di atas tampak tokoh saya yang berpikiran untuk mencelakai kedua anak Malvin dengan menggunakan botol Coca Cola. Ia berpikir bahwa apabila di gedung apartemen tersebut ada mesin penjual 
Coca Cola, maka akan banyak orang yang membelinya dan kemudian banyak pecahan botol yang berserakan di apartemen tersebut. Ia pun membayangkan kedua anak tersebut yang terjatuh lalu kepalanya terkena serpihan kaca botol. Hal ini membuat tokoh saya berusaha untuk menyediakan mesin penjual Coca Cola di apartemen tersebut. Ia berniat mendekati manajemen apartemen yang baru dipilih dan me-lobby mesin Coca Cola tersebut.

Tidak hanya itu, di lain kesempatan tokoh saya pun masih berencana untuk mencelakai keluarga tersebut. Hal ini dapat dilihat pada kutipan berikut.

Memang, cita-cita saya longsor. Tapi saya tahu keluarga Meek tidak akan tinggal di sini selama liburan Thanksgiving. Mulai tanggal 21 November tentu banyak orang bepergian ke luar kota, menginap, dan kembali tanggal 26 November. Menjelang Melvin sekeluarga pergi, saya harus memasukkan sedikit pasir ke tangki bensinnya, dan menusukkan bannya dengan jarum kecil, yang akan menggemboskan bannya dalam waktu dua puluh empat jam. Tunggu saja, Meek, tunggu. Memang, saya menunggu saat yang baik. Menunggu, menunggu, terus menunggu. Saya sudah tahu betul di mana mobil itu biasanya diparkir, dan saya tahu betul tangkinya mudah dibuka dengan mata telanjang (Darma, 2004, hlm. 72).

Menjelang perayaan Thanksgiving, tokoh saya lagi-lagi berencana ingin mencelakai keluarga Melvin melalui mobilnya. Ia berencana ingin memasukkan pasir ke dalam tangki bensinnya. Tidak hanya itu, ia berniat menusukkan sebuah jarum kecil di ban mobilnya. Dengan upaya ini, tokoh saya membayangkan mobil keluarga Melvin akan mengalami kerusakan dan mogok sehingga menghambat perjalanan mereka.

\section{Kegagalan Menjadi Subjek Radikal}

Dari pemaparan sebelumnya, tampak bahwa tokoh saya menjadi psikotik dan pada tataran lain ia benarbenar ingin lepas dari dimensi simbolik untuk memenuhi hasrat agar mencapai kepenuhannya. Namun, hal ini ternyata gagal. Meskipun ia telah menjadi subjek yang psikotik, ia ternyata kembali tunduk kepada yang simbolik, seperti yang terlihat dalam kutipan berikut.

Saya kesepian. Memang saya tidak mempunyai teman, dan memang saya sering merasa kesepian, tapi tidak pernah merasa sesepi ini. Sore itu saya melihat hampir empat puluh mobil meninggalkan lapangan parkir, dan menjelang malam sekitar lima belas mobil amblas lagi. Mobil-mobil tersebut berdatangan kembali mulai tanggal 25 malam, disambung tanggal 26 pagi, siang, dan malam. Pada tanggal 27 pagi sebelum jam kerja sekitar dua ratus mobil sudah memenuhi lapangan parkir lagi. Dan ternyata mobil Melvin tidak ada. Tanggal 28. Tidak ada. Tanggal 29. Tidak ada. Tanggal 30. Tidak ada (Darma, 2004, hlm. 73).

Dalam penjelasan sebelumnya, tampak bahwa tokoh saya menjadi subjek yang psikotik karena mampu lepas dari jerat simbolik, yakni memilih untuk tinggal sendiri di antara semua para penghuni apartemen yang memiliki keluarga. Meski demikian, ternyata ia gagal menjadi subjek yang psikotik dan akhirnya kembali kepada yang simbolik. Ketika semua tetangga apartemennya melakukan liburan bersama keluarga dan bersenang-senang, ternyata ia merasa kesepian. Momen kesepian inilah yang 
menunjukkan bahwa tokoh saya telah kembali pada jerat yang simbolik.

Tidak hanya itu, tokoh saya juga mengalami keterjeratan kembali kepada yang simbolik ketika objek hasratnya hilang dan ia mengalami keterguncangan, seperti yang digambarkan dalam kutipan di bawah ini.

Saya tetap tidak mengerti bagaimana perasaan saya sendiri. Pada waktu berjalan, seolah-olah saya merasa tidak menapak di atas lantai. Pada waktu makan, kadang-kadang saya lupa mengunyah, dan baru mengunyah setelah saya sadar lagi. Dan setelah membaca sesuatu, saya sering lupa apa yang telah saya baca. Sehabis nonton televisi, saya juga tidak tahu apa yang habis saya tonton. Dan pada waktu akan berangkat tidur, saya baru sadar bahwa kompor di dapur belum saya matikan. Dan setelah saya berangkat tidur lagi, saya ingat bahwa saya belum mematikan radio, dan seterusnya (Darma, 2004, hlm. 74).

Seperti dijelaskan sebelumnya, tokoh aku sangat membenci keluarga $\mathrm{M}$. Ia bahkan mengatur berbagai strategi untuk mencelakai keluarga tersebut agar mereka mengalami cacat seumur hidup. Namun, semua yang dilakukannya tidak pernah berhasil karena tatanan simbolik yang mengungkungnya. Ia tidak pernah bisa lepas dari yang simbolik. Ia tidak bisa memenuhi hasratnya untuk melakukan hal yang "tidak baik" tersebut.

Namun, ada anomali di sana. Ketika mendapati keluarga tersebut benar-benar cacat fisik karena kecelakaan, ia bukannya senang. Malahan ia mengalami keterguncangan karena objek hasratnya telah hilang. Akibatnya, keadaan ini membawanya pada momen kekosongan. Dalam kutipan di atas, tampak subjek menjadi linglung. Semua hal yang dilakukannya tampak "abnormal". Ia mengalami psikosis dan menunjukkan kemurniannya sebagai subjek yang rapuh, yang tidak berdaya untuk keluar dari tatanan simbolik.

Ketika subjek bisa terlepas dari tatanan simbolik tersebut, subjek pun menjadi radikal. Dalam posisi ini, subjek dapat melakukan apa yang disebut tindakan radikal. Menurut Žižek (S. Žižek, 2008, hlm. 81), tindakan ini disebut sebagai substansi subjek, satusatunya titik yang memberikan konsistensi kepada subjek. Dengan kata lain, tindakan ini telah menghancurkan ikatan terhadap yang simbolik. Namun, tindakan ini tidak bisa dilakukan oleh subjek. Meskipun ia telah menjadi subjek psikotik, ia tidak melakukan tindakan radikal. Momen kekosongan yang ia rasakan malah membuatnya semakin larut dalam tatanan simbolik.

Di tingkat dua, saya melihat Mark menggendong adiknya. Sangat capek tampaknya. Berkali-kali Mark akan jatuh, tapi dia berusaha berjalan tegap lagi. Dan Martin mendekap tubuh abangnya dengan tangan dan kaki kirinya, sedangkan tangan kanan dan kaki kanannya masih terbebat gips. Kaku tampaknya. Seorang menawarkan diri menggendong Martn, tapi baik Mark maupun Martin menolak. Lalu saya menawarkan diri menggendong Martin. Mark menjawab, "Martin adalah adik saya. Biarlah saya gendong terus dia selama saya masih kuat." (Darma, 2004, hlm. 76)

\section{Setelah} mengalami keterguncangan akibat objek hasratnya telah hilang, ia pun kembali kepada yang simbolik. Ia menjadi subjek yang rapuh dan merasa iba terhadap keluarga Melvin yang mengalami kecacatan karena 
kecelakaan mobil yang diderita oleh mereka. Ia melakukan berbagai cara untuk memudahkan kehidupan keluarga tersebut, seperti membantu kedua anak yang dibencinya ketika kebakaran di apartemennya terjadi.

\section{Budi Darma dan Tokoh Saya}

Dalam pandangan Žižek, sebuah karya sastra merupakan hasil dari gaze atau sudut pandang yang diambil oleh pengarang. Karya sastra merupakan media bagi pengarang untuk lepas dari yang simbolik. Namun, tentu saja tidak semua pengarang mampu melampaui jerat simbolik. Apabila panggilan gaze dipenuhi oleh subjek, subjektivitas yang dihadirkan ke dalam karya sastra akan menjadi subjektivitas simbolik, tetapi apabila panggilan gaze menjadi panggilan yang otentik, subjektivitas akan hadir sebagai yang real. Dalam cerpen "Keluarga M", terlihat upaya Budi Darma untuk menghadirkan subjek yang psikotik, yakni subjek yang memiliki jarak dengan tatanan simbolik. Hal ini tidak bisa lepas dari upayanya untuk melepaskan diri dari yang simbolik melalui sebuah karya sastra. Oleh karena itu, dalam cerpen ini terdapat tindakan dari pengarang sehingga dapat dikatakan bahwa subjek dalam cerpen ini mewakili Budi Darma.

Meskipun cerpen ini menggunakan latar tempat di Amerika Serikat, Budi Darma mampu mendeskripsikan secara detail setiap suasana, lokasi, sistem masyarakat di sana, dan lain sebagainya. Hal ini dapat dilihat pada kutipan berikut ini.

Kadang-kadang saya heran mengapa banyak orang tidak kerasan tinggal di sini. Ada yang mengeluh gedung ini jauh dari sekolah anak-anak mereka, ada yang menyatakan penyelasannya mengapa gedung ini dulu dibangun dekat jalan raya federal, dengan demikian lalu lintas bising dan membahayakan anak-anak, dan ada yang jengkel karena di sini terlalu banyak anak, dan karena itu suasana menjadi gaduh, ada juga yang mengeluh karena anak-anak di sini nakal, sering berkelahi, dan merugikan anak mereka sendiri. Bahwa gedung ini jauh dari tempat umum, toh semua yang tinggal di sini mempunyai mobil. Bahwa mereka repot karena anak mereka, kan semua ini akibat mereka mempunyai anak (Darma, 2004, hlm. 55-56).

Dalam kutipan di atas, tampak Budi Darma mampu menjelaskan secara detail suasana, lokasi, dan kebiasaan yang terjadi. Selain penjelasan yang cukup detail, subjektivitas Budi darma juga tampak dalam penggunaan sapaan dalam cerpen ini, seperti yang terlihat berikut ini.

Saya berdiri di dekat tempat pembuangan sampah. "Kamu mau semua makanan ini, Buyung?" tanya saya lagi. Mereka menganggukangguk lagi. Ketika saya bertanya mana yang mereka lebih dahulu serempak mereka menuding kue. Maka bungkus kue pun saya buka perlahan-lahan. Nampak mata mereka berbinar gembira dan berkali-kali mereka menelan ludah (Darma, 2004, hlm. 68).

Dalam kutipan di atas, dapat dilihat bahwa tokoh saya menggunaan sapaan Buyung dalam percakapannya. Tentu saja sapaan yang digunakan tidak sesuai dengan latar tempat yang digunakan. Hal ini mengindikasikan adanya subjektivitas Budi Darma di dalam cerpen ini. Dengan demikian, dapat dilihat adanya subjektivitas Budi Darma melalui tokoh saya dalam cerpen ini. Budi Darma menghadirkan subjek yang psikotik di dalam cerpen ini 
sebagai bentuk negosiasinya antara dirinya dan yang simbolik. Negosiasi ini pun menghasilkan subjek yang psikotik, yakni subjek yang memiliki jarak dengan yang simbolik.

\section{PENUTUP}

Dari pembahasan yang telah dilakukan tersebut dapat dilihat bahwa subjek yang ada di dalam cerpen "Keluarga M" telah melakukan tindakan radikal untuk lepas dari jerat yang simbolik. Ia menjadi pribadi yang lajang dan memilih untuk tinggal sendiri, serta menolak beberapa aturan yang ada. Namun, hal ini tidaklah tanpa konsekuensi. Subjek yang bisa terlepas dari yang simbolik menjadi yang psikotik dan mengalami keterasingan dan kembali kepada yang simbolik. Dalam kondisi demikian, tokoh saya pun mendapat desakan dari yang simbolik dan mengalami keterbelahan. Ia harus memenuhi the other, tetapi juga harus menjadi seperti yang the other inginkan. Akibatnya, tokoh ini pun terus-menerus berfantasi terhadap objek hasrat yang telah ditetapkannya. Sampai pada ketika objek hasratnya hilang, ia mengalami semacam keterguncangan. Ketika keluarga yang menjadi objek hasratnya mengalami kecelakaan, ia sampai pada momen kosong yang membawanya menjadi subjek yang benar-benar otentik. Namun, tidak lama kemudian, ia kembali kepada yang simbolik. Dengan melihat pergerakan subjek tersebut, dapat dilihat bahwa ada keinginan Budi Darma untuk menjadi subjek yang lepas dari yang simbolik, tetapi akhirnya gagal dan lagi-lagi terjerat oleh jaring-jaring yang simbolik.

\section{DAFTAR PUSTAKA}

Akmal, R. (2015). Subjektivitas Pramudya Ananta Toer dalam Novel Perburuan: Kajian Psikoanalisis Historis Slavoj Žižek. Jurnal Jentera, 4(1), 12-23. https://doi.org/https://doi.org/10.26 499/jentera.v4i1.381

Arifin, M. Z. (2016). Labirin Sinisme Para Absurdis: Sebuah Kritik Eksistensialisme dalam Sosiologi Sastra. Surabaya: Negasi Kritika.

Darma, B. (2004). Keluarga M. In Orang-orang Bloomington (Edisi kedua). Jakarta: Metafor.

Faruk. (2012). Metode Penelitian Sastra: Sebuah Penjelajahan Awal. Yogyakarta: Pustaka Pelajar.

Rampan, K. L. (1982). Cerita Pendek Indonesia Mutakhir. Yogyakarta: CV. Nur Cahaya.

Robert, R. (2013). Subjek atau Mengapa Perempuan Tidak Eksis: Provokasi Lacan tentang seksuasi dan Tindakan Etis. In Y. A. Pareanon (Ed.), Subyek yang Dikekang. Jakarta: Komunitas Salihara dan Hivos.

Setiawan, R. (2016). Membaca Kritik Slavoj Žižek: Sebuah Penjelajahan Awal Kritik Sastra Kontemporer. Surabaya: Negasi Kritika.

Teeuw, A. (1989). Sastra Indonesia Modern II. Jakarta: Pustaka Jaya.

Zamzuri, A. (2018). Cerpen 'Matinya Seorang Penari Telanjang' Karya Seno Gumira Ajidarma dalam Perspektif Subjek Slavoj Žižek. Jurnal Aksara, 30(1). https://doi.org/http://dx.doi.org/10.2 9255/aksara.v30i1.226.1-16 
Žižek, S. (1996). I Hear You with My Eyes: or, The Invisible Master. In R. S. dan S. Žižek (Ed.), Gaze and Voice as Love Objects: Sic 1. Durham and London: Duke University.
Žižek, S. (2008). The The Sublime Object of Ideology. London and New York: Verso. 